\title{
Snille leger og arbeidsskye pasienter igjen?
}

Hvis vi virkelig ønsker et inkluderende arbeidsliv, er det mest å hente i den delen av befolkningen som utgjør den marginale arbeidskraften, de som sliter med å komme seg inn i arbeidslivet eller strever med å holde seg der. Mange befinner seg her hele livet, av ulike årsaker, som manglende sosial tilpasningsevne, kronisk sykdom eller dårlig utdanning. Andre kan bli marginalisert i kortere perioder, blant annet som følge av større livshendelser.

Mye av forskning og tiltak angående sykefravær har vært rettet mot hele gruppen av arbeidstakere. Det er stort behov for å utvikle mer målrettede tiltak og forske på spesielt utsatt grupper. I dette nummer av Tidsskriftet har Simen Markussen \& Ole Røgeberg en artikkel om sykefravær hos en slik spesielt utsatt gruppe, nemlig de som har opplevd større livshendelser (1). Undersøkelsen er gjort $i$ en periode (1993-2005) der det kan se ut som om sykefraværet ble fordoblet, uten at vi helt kan forklare hvorfor. Hovedtendensen er jo ellers at fraværet har holdt seg forbausende konstant de siste tiårene (2). Artikkelen viser at de livshendelsene forfatterne har valgt (graviditet, separasjon og ektefelles død) ikke bare gir økt sykefravær (hvilket for øvrig verken er nytt eller uventet), men at det de kaller «fraværstillegget» økte gjennom en observasjonsperiode.

Det fremgår ikke klart hva som er den egentlige hensikten med studien. Hvis det dreier seg om å belyse og forstå fravær rundt større livshendelser, slik overskriften indikerer, er en epoke med store uforklarte endringer knapt hensiktsmessig. Artikkelen kan gi inntrykk av at det egentlige målet er å forstå den kraftige økningen i sykefraværet rundt årtusenskiftet, og at de spesielle gruppene er brukt som indikatorer. I så tilfelle burde det diskuteres hvorvidt gruppen med «større livshendelser» er hensiktsmessig. Funnene indikerer at like problemer med likt funksjonstap resulterer i en betydelig økning i sykmeldingstilbøyelighet gjennom observasjonsperioden. Selv om «forskjellen mellom de eksponerte gruppene og deres kontrollgrupper økte over tid», var den relative økningen faktisk mindre hos de gravide $(65 \%)$ enn i kontrollgruppen $(93 \%)(1)$.

Forfatterne diskuterer mulige årsaker til den påviste økningen hos dem som har vært utsatt for større livshendelser. De begynner med å utelukke metodesvakheter og konkluderer med at økningen er reell, videre avviser de at endret sykdomsmønster eller endring i sammensetningen av arbeidsstyrken kan være forklaringen. De ender opp med at økningen i hovedsak må skyldes ikke-medisinske forhold.

Det er lett å følge konklusjonene så langt. Mer problematisk blir det når forfatterne konkluderer med at økningen må skyldes endringer $i$ arbeidstakernes og legenes atferd og/eller holdninger. De mener dette kan ha sammenheng med økt åpenhet rundt psykiske lidelser og økt medikalisering av normal variasjon gjennom en utvidelse av sykdomsbegrepet.

Eventuelle endrede krav i arbeidslivet drøftes først i forbindelse med metodediskusjonen. Forfatterne har liten tro på at forhold på arbeidsplassene kan forklare resultatene, selv om en nærliggende forklaring på økt fravær blant marginale arbeidstakere kunne være økte krav i arbeidslivet eller mindre toleranse for nedsatt produkti- vitet. Dette er problematisk, ikke minst fordi norsk forskning har vist at arbeidsplassenes villighet til tilrettelegging betyr mye for hvor lenge gravide kan stå i jobb (3). At arbeidsgiveres vilje til å gjøre tilpasninger er redusert i aktuelle periode, er en vel så plausibel forklaring som forfatternes konklusjon om at det må skyldes leger og pasienter.

Tiltak for å redusere sykefraværet kan som annet forebyggende arbeid inndeles i generelle, selektive og individuelle. Generelle tiltak er rettet mot alle arbeidstakere og alle arbeidsplasser. Eksempler er forslag om reduserte sykepengeytelser for alle arbeidstakere og IA-avtalen, der bedrifter, uansett fraværsnivå, bl.a. forplikter seg til å redusere fraværet. Dette er en klassisk massestrategi. Et alternativ er selektive tiltak - tiltak mot personellgrupper og bransjer med erfaringsmessig høyt fravær. Aktuelle artikkel er et eksempel på en slik tilnærming til en gruppe med høyt fravær. Dette er ellers et felt der det har vært gjort relativt lite i Norge.

Den siste tilnærmingen er den individuelle, det gjelder tiltak overfor enkeltindivider eller enkelte arbeidsplasser preget av spesielt høyt fravær. Mens det er iverksatt en mengde tiltak for å behandle og rehabilitere personer med høyt fravær, blant annet ved raskere tilbake-poliklinikker, har det vært gjort lite med bedrifter, det være seg private eller offentlige (kanskje spesielt offentlige) som vedvarende opererer med høyt fravær. Her mangler det både metoder og tiltak. Hvis jeg skulle få bestemme, ville jeg konsentrere meg mer om arbeidsplassene som arena for sykefraværsarbeid, både på generelt, selektivt og individuelt plan. Hvis flere av den marginale arbeidsstyrken skal forbli yrkesaktive, er det her tiltakene må settes inn. Når det gjelder disse, har jeg mer tro på kvalifiseringstiltak enn å tilby dem medisinsk preget poliklinisk behandling.

Det er ingen direkte forbindelse mellom årsaker til endret sykefravær og hvor tiltak best kan settes inn. Å overse arbeidsplassen som en mulig forklaring på endringer er likevel problematisk fordi det vil kunne få konsekvenser for eventuelle tiltak. Det er stor forskjell på hvorvidt hovedvekten skal legges på lege og pasient eller på arbeidsplassen hvis vi ønsker å holde permanent eller midlertidig marginaliserte $\mathrm{i}$ arbeid mest mulig og lengst mulig.

\section{Dag Bruusgaard}

dag.bruusgaard@medisin.uio.no

Institutt for helse og samfunn

Universitetet i Oslo

Dag Bruusgaard (f. 1940) er professor emeritus og leder av den nasjonale forskningsetiske komité for medisin og helsefag.

Forfatter har fylt ut ICMJE-skjemaet og oppgir ingen interessekonflikter.

\footnotetext{
Litteratur

- Markussen S, Røgeberg O. Sykefravær rundt større livshendelser. Tidsskr Nor Legeforen 2012; 132: 1231- 4 .

2. Ose SO, Bjerkan AM, Pettersen I et al. Evaluering av IA-avtalen (2001-2009). SINTEF-rapport A11947. Trondheim: SINTEF, 2009.

3. Strand K, Wergeland E, Bjerkedal T. Job adjustment as a means to reduce sickness absence during pregnancy. Scand J Work Environ Health 1997; 23: 378-84.
} 